\title{
Relations between ultrastructure of mitotic spindle and chromosome translocation
}

\author{
JADWIGA A. TARKOWSKA
}

Department of General Botany, Institute of Botany, Warsaw University, Krakowskie Przedmieście 26/28, 00-927 Warszawa, Poland

(Received: February 12, 1981)

\begin{abstract}
Dividing endosperm cells of Haemanthus katherinae Bak. treated with an Q.25 per cent mixture of water-soluble glycosides from Nerium oleander were insepected in a light microscope (LM) and severe disturbances were found in all phases of mitosis. The same cells were observed in the electron microscope (EM) and relations were noted and analysed between the chromosome arrangement and the submicroscopic structure of the mitotic spindle. The successive steps in the disintegration of the formed spindle are described: fragmentation of all microtubules (MTs) starting from the poles, disappearance of non-kinetochore $\mathrm{MTS}_{\mathrm{S}}$ and further the external $\mathrm{MT}_{\mathrm{S}}$ of the kinetochore bundle. The central (internal) parallel ones remain the longest at the kinetochores. Oleander glycosides cause disintegration of the existing MTs and prevent formation of new ones. The causes of restitution transformations in the successive phases of mitosis are discussed.
\end{abstract}

\section{INTRODUCTION}

The knowledge of the structure and function of the mitotic spindle is generally considered as the key to elucidation of the mechanism of mitosis, and above all of the most essential moment of the latter, that is chromosome translocation in anaphase. Experimental studies with the use of various physical and chemical factors disturbing the normal course of mitosis are considered of great importance. From this aspect a number of antimitotics have been tested with reference to their selective action on the particular phases of mitosis.

Best known is the classical compound evoking definite types of disturbances in cells division, colchicine. Östergren $(1944,1950)$ gives schemes of the characteristic chromosome arrangement in dependence 
on the degree of impairment of the mitotic spindle. As demonstrated by further investigations, a similar chromosome arrangement (lack of metaphase plate, multipolar anaphases, dispersed chromosomes etc.) in the course of an abnormal course of mitosis may be the result of various disturbances in the structure and function of the spindle. They cannot, therefore, be interpreted unequivocally without detailed studies in the electron microscope (EM).

Elucidation of the reaction of microtubules (MTs) to the tested agent may be found in biochemical investigations. Nevertheless, in view of the processes of synthesis, polymerisation and depolimerisation of tubuline as well as the conditions and enzymatic processes accompanying these transformations, the establishment of the mechanism of action of the factor applied in the experiment is extremely difficult.

A mixture of water-soluble oleander glycosides is one of the substances evoking major disturbances in the movements of chromosomes during mitosis, associated with the impairment and inactivation of the spindle. In vitro investigaltions of dividing Haemanthus endosperm ( $\mathrm{T}$ a $\mathrm{r}$ $\mathrm{k} \mathrm{ow} \mathrm{ska} \mathrm{1976)} \mathrm{allowed} \mathrm{to} \mathrm{follow} \mathrm{precisely} \mathrm{the} \mathrm{kind} \mathrm{and} \mathrm{sequence} \mathrm{of}$ the disturbances evoked, but they did not reveal the causes of the abnormal movements of the chromosomes.

The present study was undertaken with the purpose of examining at the submicroscopic level the structure of the mitotic spindle in dividing endosperm cells treated with water-soluble oleander glycosides and of establishing the eventual dependences between the mitotic spindle structure and the chromosome arrangement. These investigations may contribute to the knowledge of the conditions indispensable for normal separation of chromosomes to the daughter cells.

\section{MATERIAL AND METHODS}

The material consisted of endosperm cells of Haemanthus katherinae Baker. As antimitotic substance an 0.025 per cent aqueous solution of oleander glycoside mixture (Oleander Gesamtglicoside Laborchemikalien, Carl Roth OHG, Karlsruhe-Wiest) was applied. Preparation for inspection in the EM began by in vitro observations (T a r k ow s k a 1976, 1978, 1979) aîter Molè- $\mathrm{Ba} \mathrm{jer}$ and $\mathrm{B}$ a jer (1968). The time of exposure of the dividing endosperm cells to the action of oleander glycosides was $30 \mathrm{~min}$ to $2 \mathrm{~h} 30 \mathrm{~min}$; as zero time was considered $5 \mathrm{~min}$ after addition of the solution, with the presumpltion that within this time the solution will permeate through the diffusion membrane and reach the cells.

Dividing cells with specially interesting abnormal chromosome patterns were chosen for inspection in phase contrast and the same cells were further inspected in the EM. The observations were performad and photographs taken in a Siemens IA electron microscope at $80 \mathrm{KV}$. 
In the description of the particular mitosis phases the cells were classified to the phases in which they were at the moment of fixation, this not corresponding to the phase in which the action of the glycosides on the cell started.

\section{RESULTS}

Cells in various phases of division were studied in the EM. Particular attention was devoted to the behaviour of the mitotic spindle, its arising in prophase and prometaphase and its reaction to the active factor of the already formed mitotic apparatus in meta- and anaphase.

\section{PROPHASE}

The effects of glycoside action in prophase are the more pronouned the more advanced are the changes inside the nucleus at the moment of penetration of the glycosides and the longer is the time of their action. Short $(40 \mathrm{~min})$ exposure of the glycosides in early or middle prophase does not essentially change the appearance of the cell (Fig. 1). The latter is similar to the control cell many times described by Bajer et al. (B a j e r 1966a, b, B a j e r and M o lè - B a j e r 1969). When exposure is longer ( $1 \mathrm{~h}$ or more) translocation of small cell organelles may occur and their greater accumulation on the future cell poles. This does not mean, however, that the typical clear zone is formed. The MTs are short and their number is markedly smaller than in control cells, whereas the amount of various-shaped vesicular endoplasmic reticulum (ER) increases.

When the action of glycosides is prolonged to about $2 \mathrm{~h}$ and started in early or middle prophase, nearly always restitution changes are observed in the LM, leading to an interphase. The fragment of such a cell is shown in Fig. 2. Noteworthy is the absence of MTs, although the internal structure of the nucleus indicates that they should be present.

Observation of prophase endosperm cells of Haemanthus in the EM reveal that oleander glycosides inhibit the formation or development of the clear zone. In all cases the MTs were less numerous and shorter than indicated by the degree of advancement of prophase transformation in the nucleus. Comparison with control material proves that the glycosides do not affect the structure of prophase chromosomes.

Striking in all observations is the occurrence of a large number of membraneous structures and vacuoles. The former were identified as endoplasmic reticulum, and their presumed role is the subject of a separate publication ( $\mathrm{T}$ a $\mathrm{rk}$ ow s k a 1979). 
Fig. 1. Middle prophase. Forty minutes action of glycosides. Numerous short MTs close to the nuclear envelope. $\times 10000$

Fig. 2. After $1 \mathrm{~h} 45 \mathrm{~min}$ of experiment. Clear zone not differentiated, MTS absent, among organelles numerous ER vesicles of various shapes $\times 3500$. a - microphotographs of cells in plastic before sectionihg. $\times 1000$

Fig. 3. Prometaphase -1 h $45 \mathrm{~min}$ after glycoside application. Not numerous central MTs only at kinetochores (arrow); between chromosomes and on the cell periphery very narrow ER cisternae are present. $\times 2500$

Figs. 4 and 5. The same cells as in Fig. 3, different section. a - microphotograph of cell in plastic before sectioning. $\times 1000$

Fig. 4. Short (fragmented) $\mathrm{MT}_{\mathrm{S}}$ at sister kinetochores. $\times 7000$

Fig. 5. Very short kinetochore $\mathrm{MT}_{\mathrm{S}}$ arranged almost parallelly, beside them on right long narrow ER cistern. $\times 20000$

\section{PROMETAPHASE}

The changes evoked by oleander glycosides run in prometaphase in various directions and are important in their consequences (cf. in vitro investigations, Tarkowska 1976). Submicroscopic pictures indicate a severe damage to the forming mitotic spindle. As early as after $1 \mathrm{~h}$ the picture of the cell changes. The MTs are less numerous and short and their normal ordered arrangement in the kinetochore bundle is greatly disturbed. The distinction of the MTs type i.e. kinetochore (k-MTs) or non-kinetochore (nk-MTs) is impossible even at a small distance from the kinetochore. Immediately at the kinetochores the MTs arrangement is in general divergent (fan-like), that is characteristic for control cells. Longer exposure ito glycosides (1 h $45 \mathrm{~min}$ ) destroys still more the MTs: they are noit numerous, usually short, visible almost exclusively at the kinetochores (Figs. 3-5). It is above all the external MTs of the kinetochore bundle that undergo destruction. The remaining internal ones are arranged almost parallelly (Fig. 5).

\section{METAPHASE}

In normal metaphase with completely developed mitotic spindle identification of $\mathrm{k}-\mathrm{MT}_{\mathrm{S}}$ and $\mathrm{nk}-\mathrm{MT}_{\mathrm{S}}$ in the EM, particularly in the peripheral parts of the spindle causes no major difficulties.

Action of oleander glycosides for $40 \mathrm{~min}$ on a cell where the chromosomes form a regular plate is sufficient to severely disorganise the spindle, and identification of $\mathrm{MT}_{\mathrm{S}}$ type far from the kinetochore is very difficult. (Fig. 6). It would seem, however, that the nk-MTs are more susceptible to the glycosides. Kinetochore microtubules form bundles diverging from the kinetochore, and their number probably remains un- 







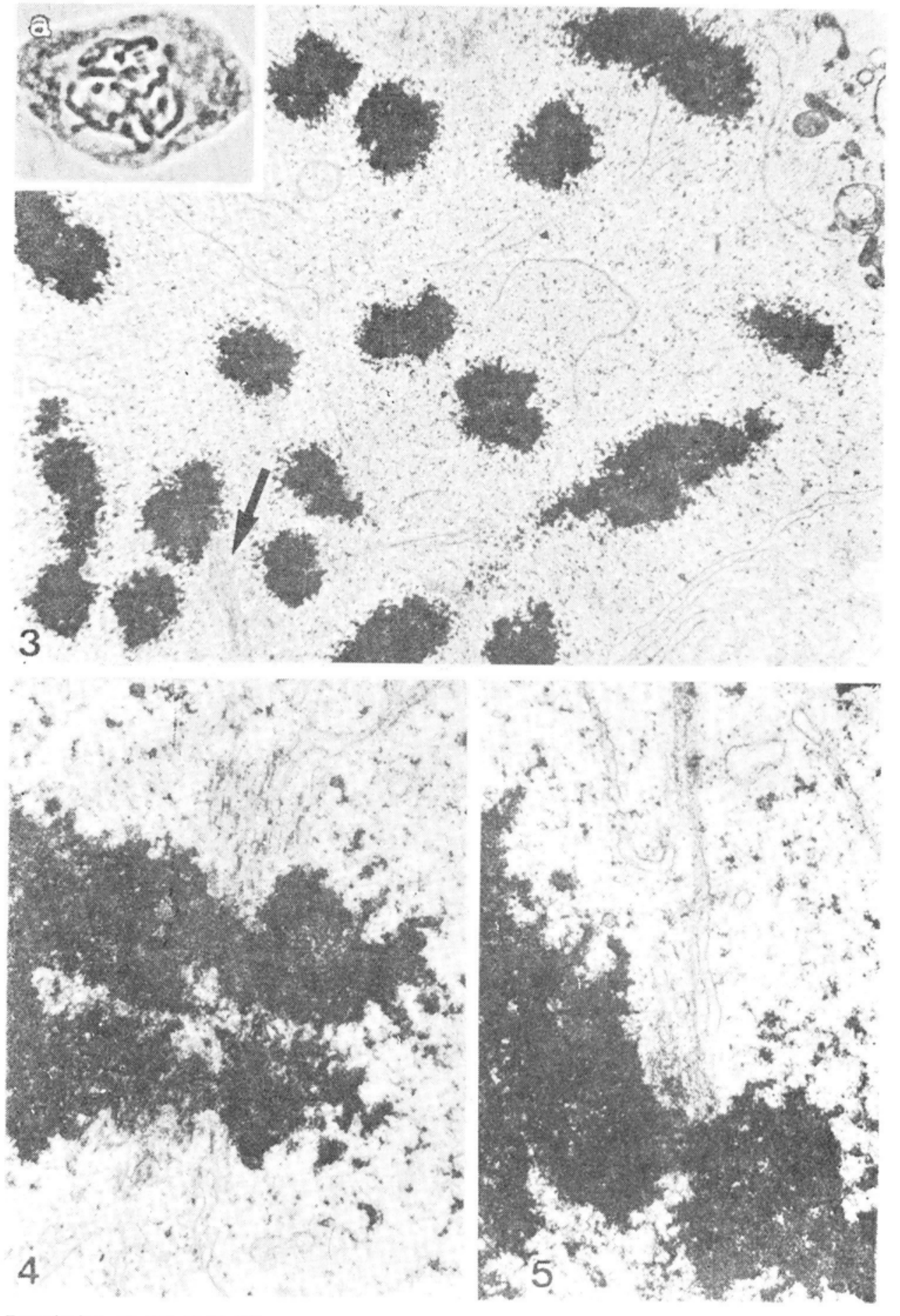

Description on the page 588. 


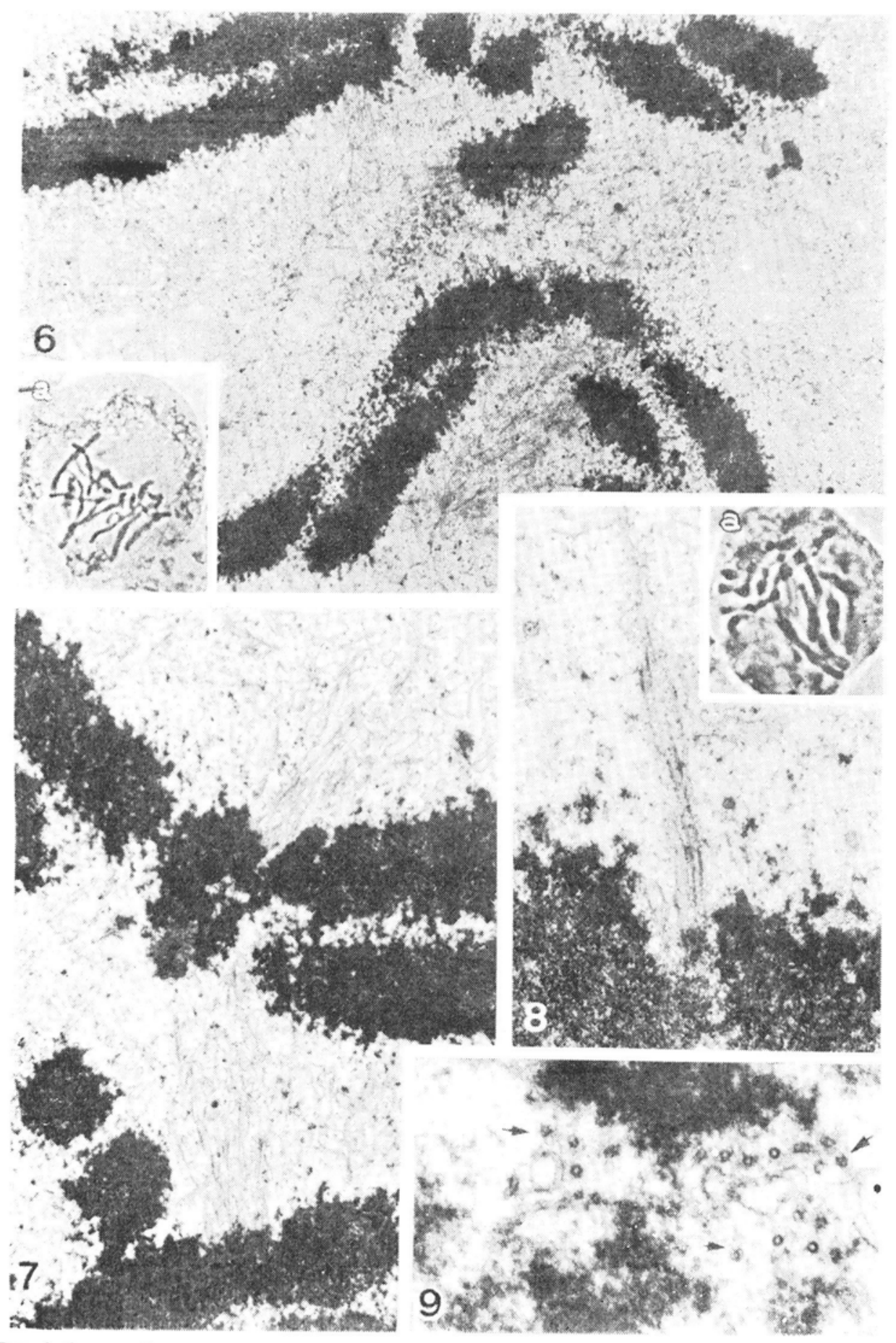

Description on the page 589 

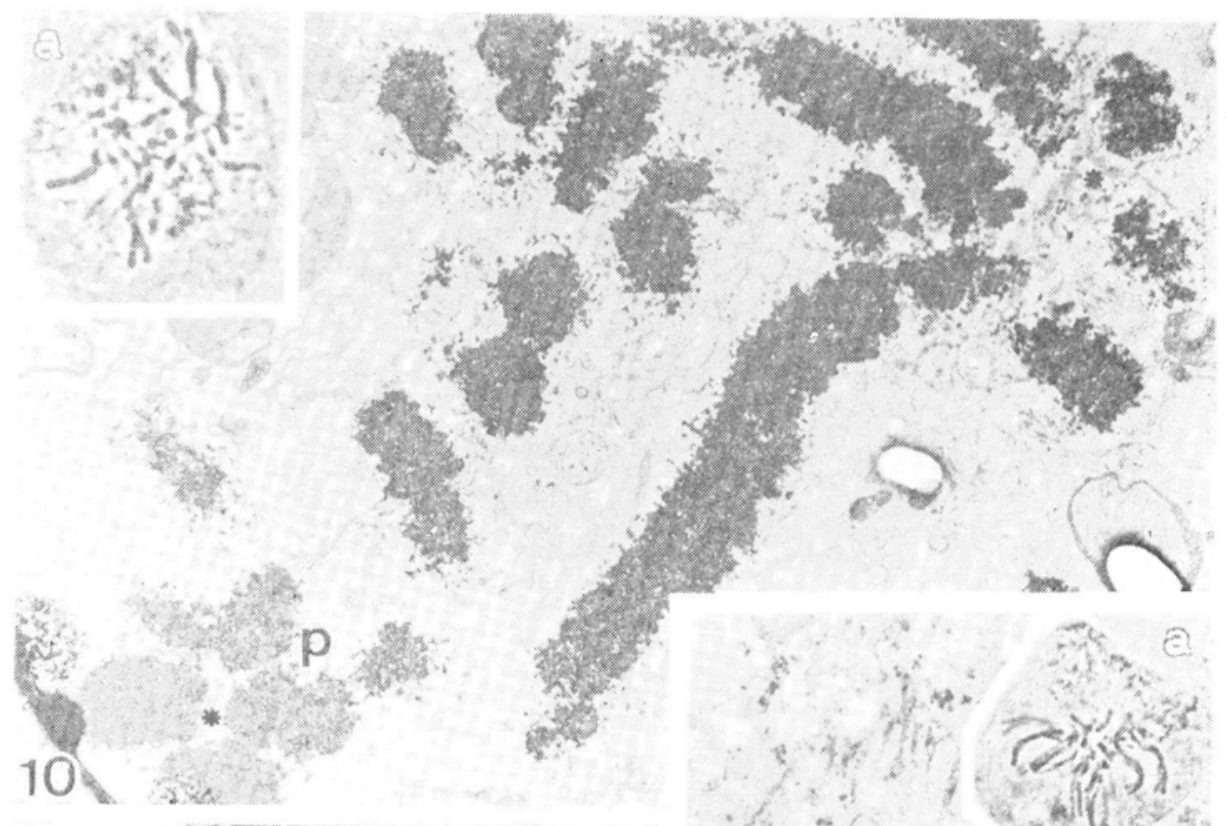

1. $14 \%$



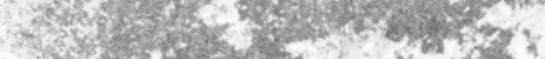

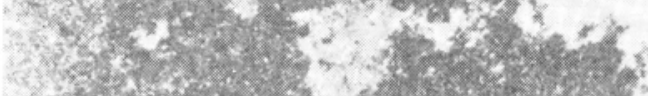
Xis.

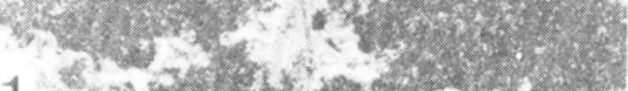

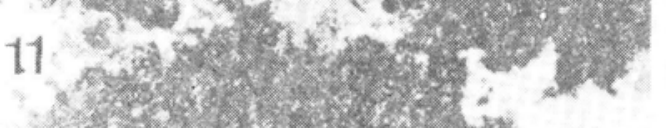

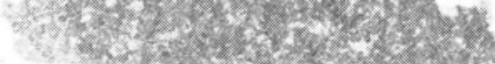

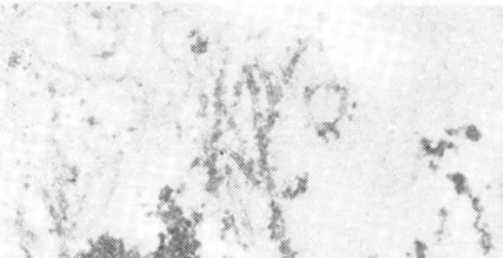

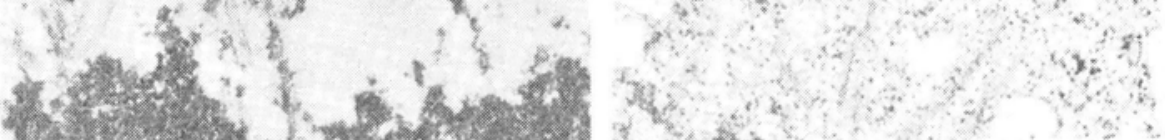

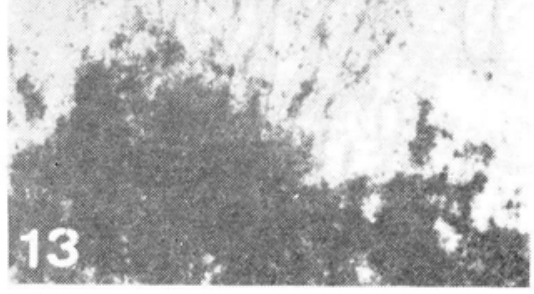

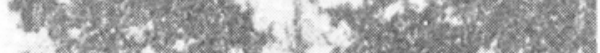
c. 3 .




c.

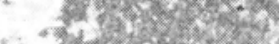


thes.
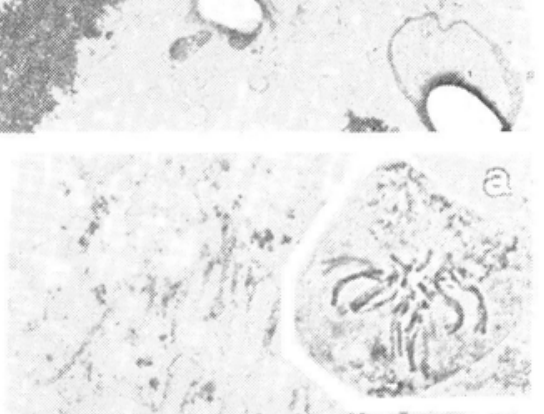

3) 13

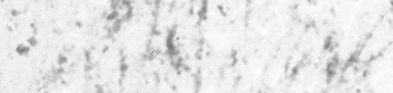

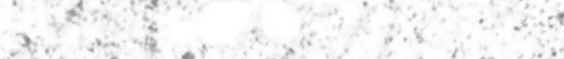
(4. 
Fig. 6. Metaphase $-40 \mathrm{~min}$ after application of cleander glycosides well visible $\mathrm{MT}_{\mathrm{S}}$ in kinetochores and some not connected with kinetochores. $\times 2800$

Fig. 7. The same cell as in Fig. 6. Kinetochore MTS shorter than in control, arranged somewhat divergently in respect to kinetochores. $\times 6000$

Fig. 8. Metaphase $-1 \mathrm{~h} 45 \mathrm{~min}$ of experiment. Several parallel MTs from kinetochore. $\times 20000$

Fig. 9. The same cells as in Fig. 8. Kinetochore MTs in cross section (arrows). a - microphotographs of cells in plastic before sectioning. $\times 1000$

Fig. 10. Anaphase $-2 \mathrm{~h} 20 \mathrm{~min}$ after oleander glycoside application. Tripolar chromosome arrangement (asterisks); at kinetochores several short MTs. $X 800$

Fig. 11. Enlarged fragment (one pole - p) from Fig. 10. $\times 10000$

Fig. 12. The same cell as in Fig. 10. Central $\mathrm{MT}_{\mathrm{S}}$ of kinetochore bundle. $\times 20000$ Fig. 13. Very early anaphase, $40 \mathrm{~min}$ of experiment. Kinetochore with fragmented MTs arranged divergently. $\times 15000$

Fig. 14. Anaphase chromosome from which restitution nucleus will arise, $1 \mathrm{~h}$ of experiment. Several very short kinetochore MTs divergently arranged. $\times 20000$. a - microphotographs of cells in plastic before sectioning. $\times 1000$

changed, that is the same as that at the moment of exposure to the glycosides. All the MTs, however, are short and fragmented (Fig. 7). Prolongation of the action of glycosides to $1 \mathrm{~h} 45 \mathrm{~min}$ greatly reduces the number of MTs at the kinetochores. On cross sections about $40 \mathrm{MTs}$ were counted at the kinetochore, but on the cross section plane they are of course less numerous (Fig. 9). The arrangement of the remaining MTs is distinctly parallel (Fig. 8).

\section{ANAPHASE}

Observations in vitro ( $\mathrm{T}$ a $\mathrm{rk}$ ow sk a 1976) demonstrated that short exposure to glycosides of the formed mitotic spindle does not produce such drastic disturbances in mitosis as in the period of spindle organisation. Usually two polar anaphases are attained, but multipolar ones may also form, and sometimes polyploid restitution nuclei.

Very early anaphase after $40 \mathrm{~min}$ of exposure to glycosides resembles the metaphase cell (after the same lapse of time), where determination of the MTs type far from the kinetochore is difficult on account of the considerable fragmentation of all the MTs of the spindle (Fig. 13). It seems, however, that the number of MTs of both types remains the same as in the control cells of early metaphase.

The submicroscopic picture is quite different when there are distinct signs of formation of restitution nuclei (after $1 \mathrm{~h}$ ). The MTs are scarce, barely several at the kinetochore in the cross section plane. These are 
the central MTs of the kinetochore bundle with a slightly divergent, less frequently parallel, arrangement (Fig. 14).

The tripolar anaphase with chromatid bridges (after $2 \mathrm{~h} 20 \mathrm{~min}$ ) is illustrated in Fig. 10. At the kinetochores there are short fragments of MTs - in the cross section plane there are 3-7 of them (Fig. 12). At each pole there is a distinct system of such Mts connecting the pole with the kinetochores of the surrounding chromosomes (Fig. 11). The sporadically occurring MTs lying beyond the kinetochores (they may belong to other kinetochores) are also very short.

\section{DISCUSSION AND CONCLUSIONS}

In vitro studies ( $\mathrm{T}$ a $\mathrm{rk}$ o w s k a 1976) showed that chromosome translocation during division of the nucleus under the influence of oleander glycosides does not run normally. By way of restitution transformation of polyploid nuclei or, as the result of uneven chromosome separation, multinuclear cells are formed with different accidental numbers of chromosomes. The disturbances involve those phases of mitosis in which the mitotic spindle is organised and functions.

Early prophase cells subjected to the action of glycosides divide no more as a rule, they start restitution transformations. Only late prophase nuclei may pass (though not frequently) to further phases of mitosis. Formation of polyploid nuclei by way of restitution transformation is a frequent phenomenon in all division phases.

EM studies indicate that, when cells in advanced prophase (with distinct clear zone) are exposed to oleander glycosides, these compounds destroy the existing MTs, and new ones are not formed. This is confirmed by the complete absence of MTs after $2 \mathrm{~h}$ or more of glycoside action (Fig. 2), whereas in the control cells MTs are numerous around the nuclear envelope. This lack of MTs is the main cause of arrest of nuclear division and the beginning of restitution transformations.

The properties of glycosides making formation of new MTs impossible and leading to destruction of the existing ones are confirmed by the results of exposure to their prolonged action ( $1 \mathrm{~h} 45 \mathrm{~min})$ of the prometaphase (Figs. 3-5) which is the main period of mitotic spindle formation. The MTs of the central part of the kinetochore bundle remain unimpaired for the longest time and they are arranged either parallelly or close to parallel.

The question arises what may be the factor making MTs formation impossible. It is believed (among others: A 11 e n and B ow en 1966, $\mathrm{Bajer}$ and Molè-Bajer 1969) that ribosomes take part in the synthesis of proteins serving for the construction of MTs. Inhibition of tubulin synthesis, however, must have some other cause in the case of 
glycoside treatment, since the occurrence of a large number of ribosomes and polyribosomes forming characteristic spirals is observed. It is possible that we are dealing here with processes analogous to the action of colchicine which binds tubulin, making formation of $\mathrm{MT}_{\mathrm{S}}$ as structural units (polymerisation) impossible. This supposition, however, requires in the case of glycosides further investigations.

It results from the here reported observations that oleander glycosides inhibit formation of new MTs and cause a successive reduction of the number of the already existing ones, the greater the longer the cells remain in the inhibitor solution. A great deal may be learnt from the abservation of metaphase and early anaphase cells when the spindle is completely formed. The destructive action of glycoside causes at first breakdown of the spindle MTs into short segments (Fig. 13). This fragmentation starts at the poles and advanices towards the equatorial part of the cell. The MTs at the kinetochores remain unimpaired longest, they are arranged fan-like there (diverging from the kinetochore) forming rather regular bundles (Fig. 7). Somewhat further from the kinetochores the arrangement of MTS is chaotic. The next step in the action of glycosides (prolonged time) on the spindle is a gradually progressing diminution of the number of MTs involving first the nk-MTs ones and then the outer MTs of the kinetochore bundle. The continuing process of breakdown leads to a state in which of the whole fan-shaped bundle there remain only the central k-MTs. They usually are short and their arrangement is as a rule parallel (Fig. 8), only sporadically it may be slightly divergent from the kinetochore. Thus, the MTs of the kinetochore bundle show a different susceptibility to the action of glycosides.

It would seem, on the basis of the electronograms, that nk-MTS disappear earlier. Their higher sensitivity under the experimental conditions is also pointed out by Brinkley et al. (1967), Ba jer et al. (1975) after the action of colcemide and by B a je r et al. (1975), L a mbert and Bajer (1977) after the application of low temperature. When oleander glycosides are applied, particularly in the first stage of their destructive action, conclusions concerning the presence and number of MTs must be drawn with caution on account of the already mentioned disorganisation of the spindle and its poles and of the disturbances in the chromosome movements and different position of the kinetochores.

It results from in vitro ( $\mathrm{T}$ a rkowska 1976) and submicroscopic observations that there exists a close dependence between the chromosome arrangement in the cell and the structure of the mitotic spindle.

Attempts to determine the number of $\mathrm{MT}_{\mathrm{S}}$ at the kinetochore, indispensable for shifting the chromosome to a definite place have so far been unsuccessful. It is known, however, that for instance in the 
control cells of Haemanthus endosperm during metaphase the number of MTs at the sister kinetochore is about 120 ( $\mathrm{Jansen}$ and B a jer 1973 ) and the reduction of their number to about one third immediately arrests the movement of the kinetochores ( $\mathrm{L} \mathrm{a} \mathrm{mbert}$ and $\mathrm{Bajer}$ 1977 , action of low temperatures).

When oleander glycosides are applied the chromosome movements in prometaphase depend both on the degree of advancement of spindle development at the moment of contact with them and on the degree of damage to the spindle caused by the glycosides. These two factors are decisive for the formation of the metaphase plate or the formation of hypoploid nuclei or else one polyploid nucleus (when k-MTs are severely impaired).

In metaphase and early anaphase fragmentation of all MTs in the polar parts of the spindle, with still, however, well preserved ones at the kinetochores (k-MTs) always reduces the range of anaphase chromosome movements. Sometimes their uniform distribution may occur, nevertheless, the distance between the daughter nuclei formed is small, they reach at most half way between the equator and the pole. Shifting of the kinetochores away from the plate in various directions is more frequent, and more or less dispersed chromosome patterns form and, as consequence, hypoploid nuclei or one polyploid nucleus. When disintegration of $\mathrm{MTS}_{\mathbf{S}}$ is so severe that there remain only some few, usually central parallel k-MTs, the chromosome movements cease and as a rule restitution nuclei arise.

Multipolar anaphases are usually the result of formation of a multipolar spindle. This has been demonstrated among others by $\mathrm{Hepler}$ and $\mathrm{Jacks}$ on (1969) in the Haemanthus endosperm as well after treatment with IPC (isopropyl N-phenylcarbamate). Under the infuence of glycoside, reduction of the number and length of the MTs occurs simultaneously with the change of the spindle shape.

Most resistant to the action of oleander glycosides are the central MTs of the kinetochore bundle, usually parallel and accompanied by long narrow ER cisternae. Both these structures may be joined by transverse arms, and as it seems, may play an important role in chromosome translocation to small distances ( $\mathrm{T} \mathrm{ark} \mathrm{owska} \mathrm{1978).} \mathrm{The} \mathrm{great}$ reduction of the $\mathrm{k}-\mathrm{MTS}_{\mathrm{s}}$ number and their arrangement parallel to one another should, however, be considered as the main causes of inhibition of kinetochore movements. B a jer et al. (1975) called attention to the relation after the action of chloralhyldrate, colcemide and low temperature. A detailed analysis of the dependence of the kinetochore movement and submicroscopic structure of the spindle after the action of low temperature is given by $\mathrm{La} \mathrm{m} \mathrm{bert} \mathrm{and} \mathrm{B} \mathrm{a} \mathrm{jer} \mathrm{(1977)} \mathrm{(all} \mathrm{inve-}$ stigations on Haemathus endosperm cells). The authors found that ar- 
rest of the kinetochore movement in the prometaphase-anaphase period is the result of disappearance of nk-MTs and reduction of the k-MT number to one third as compared with the control material. The remaining k-MTs were straight, clustered and parallel to one another, but they were not necessarily MTs of the central part of the bundle. Removal of the active factor and return to the divergent MTs arrangement from the kinetochores produces almost immediately a return of chromosome movement.

Arrest of division of the nucleus and the beginning of restitution transformation so frequently observed during the action of glycosides may have two causes:

1) the lack of a formed mitotic spindle due to inhibition of synthesis (polymerisation) of MTs - in prophase and prometaphase;

2) the lack of $n k-\mathrm{MT}_{\mathrm{s}}$ and a considerable reduction of the number of $\mathrm{k}-\mathrm{MT}_{\mathrm{S}}$ with simultaneous very marked shortening and a tendency to parallel arrangement of the remaining MTs - independently of the chromosome arrangement in the cell, that is in all division phases. It results from the author's observations that a condition for normal chromosome movement (prometaphase-anaphase) is the presence of a sufficiently large number of suitably long microtubules divergently (fan-like) running from the kinetochores. Each of these conditions is important, but not exclusive for normal chromasome movement. It would seem, on the other hand, that the greater susceptibility and early disappearance of nk-MTs are of no major importance.

Acknowledgment

I would like to think Professor dr J. Szuleta for critical reading of the manuscript and constructive suggestions.

\section{REFERENCES}

Allen R. D., Bowen C. C., 1966. Fine structure of Psilotum nudum cells. Caryologia 19: 229-342.

Bajer A., 1966a. Morphological aspects of normal and abnormal mitosis. Konf. Deut. Naturforsch. Arzte, Vienna, 1965, In: Probleme der Biologischen Reduplikation. Springer-Verlag, Berlin and New York. pp. 90-119.

B a jer A., 1966b. Movements within the mitotic spindle. In: Dynamics of fluids and plasmas. Acad. Press. New York. pp. 59-80.

B a jer A., Molè-Bajer J., 1969. Formation of spindle fibers, kinetochore orientation and behaviour of the nuclear envelope during mitosis in endosperm. Chromosoma 27: 448-484.

B a jer A. S., Molè-B a jer J., L a m bert A. Mi., 1975. Lateral interaction of microtubules and chromosome movements. In: Miorotubules and Microtubule Inhibitors. Borgers and Brabander (eds.) North-Holland Publ. Camp., Amsterdam.

Brinkley B. R., Stubblefield E., Hsu T. C., 1967. The effects of colcemid inhibition and reversal on the fine structure of the mitotic apparatus of Chinese hamster cells in vitro. J. Ultraistr. Res. 19: 1-18. 
Hepler P. K., Jacks on W. T., 1969. Isopropyl N-phenylcarbamate effects spindle microtubule orientation in dividing endosperm cells of Haemanthus katherinae Baker. J. Cell Sci. 5: 727-743.

Jansen C., Bajer A., 1973. Spindle dynamics and arrangement of microtubules. Chromosoma 44: 73-89.

L a mbert A. M., B a jer A. S., 1977. Microtubule distribution and reversible arrest of chromosome movements induced by low temperature. Cytobiologie 15: 1-23.

M o lè-B a jer J., B a jer A., 1968. Studies of selected endosperm cells with the light and electron microscope the technique. La Cellule 67: 257-265.

ठstergren G., 1944. Colchicine mitosis, chromosome contraction narcosis and protein chain folding. Hereditas 30: 429-467.

Ostergren G., 1950. Cytological standards for the quantitative estimation of spindle disturbances. Hereditas 36: 371-382.

Tarkowska J. A., 1976. Investigations in vitro on the behaviour of chromosomes and the mitotic apparatus in endosperm cells of Haemanthus kathcrinae Baker treated with oleander glycosides. Acta Soc. Bot. Pol. 45: 271-283.

Tarkowska J. A., 1978. Connections between microtubules and endoplasmic reticulum in mitotic spindle. Acta Soc. Bot. Pol. 47: 411-416.

Tarkowska J. A., 1979. Endoplasmic reticulum hypertrophy and nuclear envelope formation - a postulate. Acta Soc. Bot. Pol. 48: 381-389.

\section{Ultrastruktura wrzeciona mitotycznego a przemieszczanie się chromosomów - zależności}

\section{Streszczenie}

Badano początkowo in vitro w LM dzielące się komórki bielma Haemanthus hatherinae Bak. poddane działaniu 0,025\% wodnego roztworu mieszaniny glikozydów oleandra. Następnie te same komórki utrwalano i sporządzano preparaty do badań w EM. Stwierdzono i analizowano zależności układu chromosomów i budowy submikroskopowej wrzeciona mitotycznego. Obserwowane nieprawidłowości w podziałach komórek są wynikiem rozpadu, a następnie zaniku (depolimeryzacji) MTs, oraz zahamowania tworzenia się (polimeryzacji) nowych MTs. Niszczenie uformowanego wrzeciona przebiega etapami:

1) fragmentacja wszystkich $\mathrm{MTS}_{\mathrm{S}}$ rozpoczynająca się na biegunach i postępująca w kierunku równilkowym komórki; 2) w.cześniejsza depolimeryzacja MTs niekinet.)chorowych; 3) rozpad $\mathrm{MTS}_{\mathrm{S}}$ wiązki kinetochorowej rozpoczynający się od MTs zewnętrznych - najdłużej pozostają środkowe, zwykle równoległe MTs tej wiązki.

Fragmentacja $\mathrm{MTS}_{\mathrm{S}}$ przy biegunach powoduje zmniejszenie zasięgu ruchu chromosomów, a silna redukcja ich liczby przy kinetochorach i równoległy wzajemny układ są przyczyną zatrzymania ruchu chromosomów. Zatrzymanie podziału jądra i rozpoczęcie przemian restytucyjnych może mieć dwie przyczyny: zahamowanie polimeryzacji tubuliny w MTs w okresie formowania się wrzeciona lub bardzo silne uszkodzenie wrzeciona już wykształconego (depolimeryzacja MTs). Warunkiem prawidłowych ruchów kinetochorów jest obecność dostatecznie dużej ilości, odpowiednio długich i rozbieżnie (wachlarzowato) od kinetochoru biegnących MTs. Wydaje się, że większa swrażliwość i wcześniejsza depolimeryzacja $\mathrm{MT}_{\mathrm{S}}$ niekinetochorowych nie jest istotna. 